\title{
Potash use in aerobic production system for basmati rice may expand its adaptability as an alternative to flooded rice production system
}

\author{
Abdul Wakeel ${ }^{* 1}$, Hafeez Ur Rehman ${ }^{2}$, Muhammad Umair Mubarak ${ }^{1}$, Abid Ilyas Dar ${ }^{3}$ and \\ Muhammad Farooq ${ }^{2}$
}

${ }^{1}$ Institute of Soil and Environmental Sciences, University of Agriculture Faisalabad, Pakistan. ${ }^{2}$ Department of Agronomy, University of Agriculture Faisalabad, Pakistan. ${ }^{3}$ Engro Eximp. (Pvt.) Ltd. Dera Sarawan, Sakham, Sheikhupura, Pakistan. *Corresponding author: abdulwakeel77@gmail.com

\begin{abstract}
Direct seeded aerobic rice system has been developed and adopted as an alternative for medium-grain rice in many parts of the world, whereas efforts for aerobic basmati rice types are still in infancy. Among two major constraints for aerobic rice, weeds are progressively being eliminated to great extent through introduction of new herbicides; however, the issue of unfilled grains is still elusive. As potassium $(\mathrm{K})$ deficiency produce sterile pollens in different crops, therefore possible $\mathrm{K}$ deficiency in aerobic rice production system may increase unfilled grains in rice. Therefore, it was hypothesized that $\mathrm{K}$ application may yield better by improving grain filling of basmati rice, especially, under aerobic conditions. Pot and field experiments were comprised of no $\mathrm{K}$ as control, $\mathrm{K}$ fertilization using 90 and $180 \mathrm{~kg} \mathrm{ha}^{-1}$ keeping recommended N, P and $\mathrm{Zn}$ fertilization at the rate of 180, 125 and $25 \mathrm{~kg} \mathrm{ha}^{-1}$. Two fine grain rice cultivars Basmati-515 and Super basmati were used due to their differential response to $\mathrm{K}$ fertilization. Results indicated that application of $180 \mathrm{~kg} \mathrm{~K}_{2} \mathrm{O} \mathrm{ha}^{-1}$ significantly increased the $\mathrm{K}$ concentration in shoot, which increased the paddy yield. Highest chlorophyll contents were observed for Basmati-515 in aerobic rice and for Super basmati under flooded condition at $180 \mathrm{~kg} \mathrm{~K}_{2} \mathrm{O} \mathrm{ha}^{-1}$. Decrease in number of un-filled grains may a contributory to paddy yield improvement in $\mathrm{K}$ fertilized treatments. The improvement in yield was more pronounced in Basmati-515 than Super basmati. Economic analysis showed higher benefit cost ratio for Basmati-515 with $90 \mathrm{~kg} \mathrm{Kg} \mathrm{ha-1}$ under aerobic conditions. Net benefit of K fertilization was increased for both fertilizer rates and both cultivars except $180 \mathrm{~kg} \mathrm{~K}$ in Super basmati. As K fertilization increased the number of filled grains and improved the rice yield, therefore it is suggested to apply $\mathrm{K}$ fertilizers for better yield and expanded adaptability of aerobic rice production system for basmati rice. Availability of indigenous soil K under aerobic and flooded conditions should be quantified to develop precise $\mathrm{K}$ recommendations for both production systems of basmati rice.
\end{abstract}

Keywords: Grain filling, Basmati rice, Aerobic rice, Potassium, Water scarcity 


\section{Introduction}

Rice (Oryza sativa L.) is one of the leading staples and major contributor to food security world-wide. Conventionally transplantation of nursery seedlings into the puddled field is widespread practice for rice growing which demands huge water and labor input throughout the crop season (Farooq et al., 2007). Puddling creates a hard pan below the root zone, which decreases the soil permeability, and is a major contributor of potent greenhouse gas to environment (Wassmann et al., 2004).

Direct seeded rice (DSR) as an aerobic system is an attractive alternative to conventional flooded system (Farooq et al., 2011). When planted by direct seeding under aerobic conditions, rice establishes faster and matures earlier (Rehman et al., 2011), cuts down the crop water requirement by $30-50 \%$ (Dawe 2005) and reduces the emission of methane (Wassmann et al., 2004). This system economizes the cost of production by decreasing demand for water and labor (Farooq et al., 2011). However, erratic crop stand, more unfilled grain percentage and high weed proliferation are amongst the key limitations for its broad range adaptation (De Datta 1986; Farooq et al., 2011). The weed proliferation has been decreased to a certain extent by the introduction of new herbicides (Hussain et al., 2008; Khaliq and Matloob, 2011; Akbar et al., 2011); however, the issue of unfilled grains is still open in aerobic rice system. Reduction in unfilled grains has been reported by boron nutrition in aerobic rice (Rehman et al., 2012, 2014), but the problem is not solved yet. Shift in rice cultivation from flooded to aerobic rice system have effect on nutrients availability and soil aeration due to changes in water status (Timsina and Connor, 2001, Rehman et al., 2016). Under aerobic rice system, potassium (K) availability becomes lower due to less release from clay minerals as compared to flooded conditions. Further, K gradient from irrigation water also gets lower. Flooding of soil increases the $\mathrm{K}$ release from soils as $\mathrm{Fe}^{+3}$ and $\mathrm{Mn}^{+4}$ are converted to $\mathrm{Fe}^{+2}$ and $\mathrm{Mn}^{+2}$, under reduced conditions, which exchange $\mathrm{K}^{+}$from exchange sites of soils (Patrick et al., 1985). And as the reduction of $\mathrm{Fe}^{+3}$ and $\mathrm{Mn}^{+4}$ is completed, the $\mathrm{K}$ concentration in soil becomes constant (De Datta and Mikkelsen, 1985). Its diffusion and transport in the soil is also increased under flooded condition as increase in soil moisture can increase the $\mathrm{K}$ transport in the soil (Havlin et al., 1999). Under flooded conditions, significant amount of $\mathrm{NH}_{4}^{+}$is accumulated which can also displace $\mathrm{K}^{+}$ from the soil particles (Patrick et al., 1985).

Foliar application of $\mathrm{K}$ decreased the panicle sterility in rice (Mahajan and Khurana, 2014), and possible $\mathrm{K}$ deficiency under aerobic conditions as compared to flooded conditions may be responsible fully or partially for panicle sterility and increase in percent unfilled grains. For this study, it was hypothesized that $\mathrm{K}$ fertilization may improve the paddy yield under aerobic conditions through decrease in unfilled grains percentage. The specific objectives of the study were to compare the availability of $\mathrm{K}$ under aerobic and flooded rice production system, and to investigate the possible role of $\mathrm{K}$ fertilization in decreasing unfilled grains especially under aerobic conditions using basmati rice cultivars.

\section{Materials and Methods}

\subsection{Pot experiment}

The pot experiment was conducted in a wire house located at the University of Agriculture, Faisalabad, Pakistan during 2012. Two fine grain rice cultivars, Basmati 515 and Super basmati were used in the study because of their differential response to $\mathrm{K}$ fertilizer 
application (Zaman et al., 2015). Eight seeds each of two cultivars were sown in $20 \mathrm{~kg}$ soil earthen pots maintained as aerobic. Later, two plants per pot was kept 15 days after germination. Whereas nursery was sown at the same day separately for flooded rice system which was transplanted two seedlings per pot after 25 days. Potash was applied at 0.9 and $1.8 \mathrm{~g} \mathrm{~K}_{2} \mathrm{O}$ per pot as $\mathrm{K}_{2} \mathrm{SO}_{4}$ at sowing time, while control pots got no $\mathrm{K}$ fertilizer. Experimental soil was collected from rice growing area, where field experiment was conducted later during 2013. Physicochemical properties of experimental soil are given in Table 1.

Table 1. Physicochemical properties of soil used in experiments

\begin{tabular}{lcc}
\hline \multicolumn{1}{c}{ Parameter } & Unit & Value \\
\hline Soil texture & --- & Clay loam \\
$\mathrm{pH}$ & & 8.0 \\
$\mathrm{EC}$ e & $\mathrm{dS} \mathrm{m}^{-1}$ & 0.30 \\
Exchangeable Na & $\mathrm{mg} \mathrm{kg}^{-1}$ & 1.7 \\
$\mathrm{NH}_{4}$ - exchangeable $\mathrm{K}$ & $\mathrm{mg} \mathrm{kg}^{-1}$ & 86 \\
Boron & $\mathrm{mg} \mathrm{kg}^{-1}$ & 0.65 \\
\hline
\end{tabular}

The pots were arranged in completely randomized design with two factors, where each treatment was replicated four times considering each pot as a replication. Nitrogen $(\mathrm{N})$, phosphorus $(\mathrm{P})$ and zinc $(\mathrm{Zn})$ were applied at the rate of $1.8,1.25 \mathrm{~g}$ and $0.25 \mathrm{~g}$ per pot as urea, di-ammonium phosphate and $\mathrm{ZnSO}_{4}$.

Chlorophyll contents were measured with chlorophyll meter (SPAD 502 P) at panicle initiation. Plant height, number of grains per panicle, paddy yield, total biomass and percent unfilled grains were measured at maturity using standard procedures (Rehman et al., 2011). Filled and unfilled grains per panicle were counted and the percentage of unfilled grains per panicle was determined. Potassium concentration in shoot at maximum tillering, and in husk and grain after harvesting was determined by wet digestion in nitric and perchloric acids (Rashid, 1999) using flame photometer (Chapman and Pratt, 1961).

\subsection{Field experiment}

The field experiment was conducted in year 2013 at a farmer's field in district Sheikhupura (latitude $31.81 \mathrm{~N}$ and longitude 74.24 E; altitude $236 \mathrm{~m}$ ), Punjab, Pakistan. The experimental soil was clay loam with $\mathrm{pH} 8.0$, EC $0.30 \mathrm{dS} \mathrm{m}^{-1}$ and $90 \mathrm{mg} \mathrm{K}_{2} \mathrm{O} \mathrm{kg}^{-1}$ soil. After pre-soaking irrigation, field was ploughed twice and both rice cultivars were drilled at inter-row distance of $23 \mathrm{~cm}$ using seed rate of $50 \mathrm{~kg} \mathrm{ha}^{-1}$ on $21^{\text {st }}$ June 2013. Potash was applied at the rate of 90 and $180 \mathrm{~kg} \mathrm{~K}_{2} \mathrm{O} \mathrm{ha}^{-1}$ using $\mathrm{K}_{2} \mathrm{SO}_{4}$ as basal dose, while control was not fertilized with $\mathrm{K}$ fertilizer. The experimental treatments were arranged as randomized complete block design. Nitrogen fertilizers were applied at the rate of $180 \mathrm{~kg} \mathrm{~N} \mathrm{ha}^{-1}$ as urea and DAP, phosphorus at the rate of $125 \mathrm{~kg} \mathrm{P}_{2} \mathrm{O}_{5} \mathrm{ha}^{-1}$ as DAP and $\mathrm{Zn}$ at the rate of 25 $\mathrm{kg} \mathrm{ha}^{-1}$ as $\mathrm{ZnSO}_{4}$.

The plot size was $2.2 \mathrm{~m} \times 6 \mathrm{~m}$ and all fertilizers were applied at sowing time except nitrogen, which was applied half at sowing time and half at the tillering. Irrigation was applied once a week with $63 \%$ canal water and $37 \%$ tube-well water (fit for irrigation). Chemical as well as mechanical removal of weeds was carried out. Crop was harvested at maturity in the month of November 2013 and the grains per panicle, percent unfilled grains and paddy yield were determined following the same procedures as for pot experiment.

\subsection{Statistical analysis}

Collected data were analyzed statistically by using statistic software (Statistic 8.1). Least significance 
difference (LSD) test at 5\% probability level was applied to compare the treatments means (Steel et al., 1997).

\subsection{Economic analysis}

The economic analysis was done considering actual paddy and straw yield. Total permanent cost includes cost of seed, seed bed preparation, irrigation, plant protection, harvesting costs and land rent, whereas cost of fertilizers was considered as variable.

\section{Results}

\subsection{Plant growth and chlorophyll content}

Application of $\mathrm{K}$ fertilizer increased the plant height in both basmati cultivars in both production systems, however under aerobic condition Basmati-515 had more height as compared to Super basmati when fertilized at the rate of $180 \mathrm{~kg} \mathrm{ha}^{-1} \mathrm{~K}$, whereas under flooded conditions, varietal difference was not observed (Table 2). Application of $180 \mathrm{~kg} \mathrm{~K} \mathrm{ha}^{-1}$ significantly increased the total biomass of Super basmati in aerobic rice and Basmati-515 showed increase at the same level of $\mathrm{K}$ in flooded system only.

Super basmati did not show any increase in biomass due to $\mathrm{K}$ fertilization under flooded conditions, although the biomass production was higher than of Basmati 515. However, at $90 \mathrm{~kg} \mathrm{~K} \mathrm{ha}^{-1}$, no significant increase in biomass was observed in both cultivars and production systems.

Application of K significantly increased the chlorophyll contents in both cultivars under both aerobic and flooded conditions, except $90 \mathrm{~kg} \mathrm{~K} \mathrm{ha}^{-1}$ in Basmati-515 under flooded conditions (Table 2). Maximum SPAD value (47.2) was recorded in cultivar Super Basmati from the $\mathrm{K}$ application at 180 $\mathrm{kg} \mathrm{ha}^{-1}$ under flooded conditions; however, under aerobic conditions, maximum SPAD value (42) was recorded in cultivar Basmati 515 at the same $\mathrm{K}$ level (Table 2).

\subsection{Potassium concentration in shoot, husk and grain}

There was increase in $\mathrm{K}$ concentration of shoot, husk and grain at $180 \mathrm{~kg} \mathrm{~K} \mathrm{ha}^{-1}$ in both cultivars of rice. The increase in $\mathrm{K}$ concentration of shoot at maximum tillering was observed under both rice systems and both cultivars at $90 \mathrm{~kg} \mathrm{~K} \mathrm{ha}^{-1}$ and $180 \mathrm{~kg} \mathrm{~K} \mathrm{ha}^{-1}$ (Table 2). Similar increase in $\mathrm{K}$ concentration of husk and grain was observed by $\mathrm{K}$ fertilization at both rates. Grain K concentration ranged from 6.3 to $15.89 \mathrm{~g} \mathrm{~kg}^{-1}$ of dry mass showing a great variation and variable $\mathrm{K}$ uptake by plants. Highest $\mathrm{K}$ concentration was found at $180 \mathrm{~kg} \mathrm{~K} \mathrm{ha}^{-1}$. Under aerobic conditions, the concentration of $\mathrm{K}$ in shoot, husk and grain was lesser than under flooded conditions at all $\mathrm{K}$ levels (Table 2).

\subsection{Unfilled grains and paddy yield}

Unfilled grains were more under aerobic conditions and were significantly decreased by $\mathrm{K}$ fertilization at both levels. Application of $90 \mathrm{~kg} \mathrm{~K}_{2} \mathrm{O} \mathrm{ha}^{-1}$ decreased the unfilled grains in both rice systems which further decreased at higher $180 \mathrm{~kg} \mathrm{~K}_{2} \mathrm{O} \mathrm{ha}^{-1}$. Super basmati had more unfilled grains in aerobic system. In field experiment under aerobic conditions, similar results were found regarding unfilled grains and the difference in unfilled grains of both cultivars was wider with maximum in Super Basmati. The decrease in percent unfilled grains by application of $180 \mathrm{~kg} \mathrm{~K}_{2} \mathrm{O}$ ha $^{-1}$ in Basmati-515 in pot and field experiments was 10.3 and $3.1 \%$ respectively, whereas in Super Basmati the decrease was 10.1 and $5.2 \%$, respectively (Figure 1 and 2). Thus, $\mathrm{K}$ fertilization under aerobic 
and flooded conditions, increased the total number of grains per panicle in both cultivars.

In aerobic system, Basmati-515 yielded more number of grains per panicle, while under flooded conditions, Super Basmati produced more grains per panicle.

Table 2. Plant height, chlorophyll content, potassium concentration (shoot, husk and grain) in response to K fertilizer application in pot experiment. $\mathrm{K}_{1}=90 \mathrm{~kg} \mathrm{ha}^{-1}$ and $\mathrm{K}_{2}=180 \mathrm{~kg} \mathrm{ha}^{-1}$

\begin{tabular}{|c|c|c|c|c|c|c|c|c|}
\hline & Treatments & & $\begin{array}{c}\text { Plant } \\
\text { height } \\
(\mathrm{cm})\end{array}$ & $\begin{array}{c}\text { Shoot K at } \\
\text { maximum } \\
\text { tillering (g } \\
\left.\mathrm{kg}^{-1}\right)\end{array}$ & $\begin{array}{c}\mathrm{K} \text { in husk } \\
\left(\mathrm{g} \mathrm{kg}^{-1}\right)\end{array}$ & $\begin{array}{c}\mathrm{K} \text { in grains } \\
\left(\mathrm{g} \mathrm{kg}^{-1}\right)\end{array}$ & $\begin{array}{l}\text { Chlorophyll } \\
\text { Contents } \\
\text { (SPAD Value) }\end{array}$ & $\begin{array}{c}\text { Total biomass } \\
\left(\mathrm{g} \mathrm{pot}^{-1}\right)\end{array}$ \\
\hline \multirow[t]{2}{*}{ Aerobic } & Basmati 515 & $\begin{array}{l}\mathbf{K}_{0} \\
\mathbf{K}_{1} \\
\mathbf{K}_{2} \\
\end{array}$ & $\begin{array}{c}32 \mathrm{bc} \\
33 \mathrm{ab} \\
35 \mathrm{a} \\
\end{array}$ & $\begin{array}{l}11.28 \mathrm{c} \\
14.97 \mathrm{~b} \\
20.13 \mathrm{a} \\
\end{array}$ & $\begin{array}{l}5.57 \mathrm{~cd} \\
7.42 \mathrm{bc} \\
10.73 \mathrm{a} \\
\end{array}$ & $\begin{array}{c}7.23 \mathrm{~b} \\
10.18 \mathrm{a} \\
12.21 \mathrm{a} \\
\end{array}$ & $\begin{array}{l}27.4 \mathrm{e} \\
36.8 \mathrm{c} \\
42.0 \mathrm{a} \\
\end{array}$ & $\begin{array}{c}39.5 \mathrm{ab} \\
42.5 \mathrm{ab} \\
48.7 \mathrm{a} \\
\end{array}$ \\
\hline & Super Basmati & $\begin{array}{l}\mathbf{K}_{0} \\
\mathbf{K}_{1} \\
\mathbf{K}_{2}\end{array}$ & $\begin{array}{l}30 \mathrm{c} \\
31 \mathrm{bc} \\
32 \mathrm{~b}\end{array}$ & $\begin{array}{l}10.36 \mathrm{c} \\
14.42 \mathrm{~b} \\
19.57 \mathrm{a}\end{array}$ & $\begin{array}{l}4.84 \mathrm{~d} \\
6.31 \mathrm{~cd} \\
9.44 \mathrm{ab}\end{array}$ & $\begin{array}{c}6.31 \mathrm{~b} \\
10.73 \mathrm{a} \\
11.79 \mathrm{a}\end{array}$ & $\begin{array}{l}24.5 \mathrm{f} \\
34.7 \mathrm{~d} \\
39.8 \mathrm{a}\end{array}$ & $\begin{array}{c}37.7 \mathrm{~b} \\
40.2 \mathrm{ab} \\
47.5 \mathrm{a}\end{array}$ \\
\hline \multirow[t]{2}{*}{ Flooded } & Basmati 515 & $\begin{array}{l}\mathbf{K}_{0} \\
\mathbf{K}_{1} \\
\mathbf{K}_{2}\end{array}$ & $\begin{array}{l}36 \mathrm{C} \\
38 \mathrm{BC} \\
39 \mathrm{AB}\end{array}$ & $\begin{array}{c}12.94 \mathrm{E} \\
18.10 \mathrm{CD} \\
22.15 \mathrm{AB}\end{array}$ & $\begin{array}{c}7.78 \mathrm{~B} \\
9.63 \mathrm{AB} \\
11.84 \mathrm{~A}\end{array}$ & $\begin{array}{c}8.15 \mathrm{C} \\
12.50 \mathrm{~B} \\
14.60 \mathrm{AB}\end{array}$ & $\begin{array}{c}38.9 \mathrm{C} \\
41.4 \mathrm{BC} \\
44.7 \mathrm{AB}\end{array}$ & $\begin{array}{c}57.5 \mathrm{C} \\
68.7 \mathrm{BC} \\
73.7 \mathrm{AB}\end{array}$ \\
\hline & Super Basmati & $\begin{array}{l}\mathbf{K}_{0} \\
\mathbf{K}_{1} \\
\mathbf{K}_{2} \\
\end{array}$ & $\begin{array}{l}37 \mathrm{C} \\
39 \mathrm{~B} \\
41 \mathrm{~A} \\
\end{array}$ & $\begin{array}{c}15.15 \mathrm{DE} \\
19.57 \mathrm{BC} \\
23.63 \mathrm{~A}\end{array}$ & $\begin{array}{c}7.91 \mathrm{~B} \\
10.36 \mathrm{AB} \\
12.57 \mathrm{~A} \\
\end{array}$ & $\begin{array}{c}8.41 \mathrm{C} \\
12.72 \mathrm{~B} \\
15.89 \mathrm{~A}\end{array}$ & $\begin{array}{c}40.1 \mathrm{C} \\
44.5 \mathrm{AB} \\
47.2 \mathrm{~A}\end{array}$ & $\begin{array}{c}80.0 \mathrm{AB} \\
83.7 \mathrm{~A} \\
87.5 \mathrm{~A}\end{array}$ \\
\hline
\end{tabular}

Basmati-515 had more paddy yield under aerobic conditions while Super Basmati in flooded rice system. $\mathrm{K}$ fertilization improved the paddy yield in both cultivars and production systems. Maximum paddy yield was observed in Super Basmati at both 90 and $180 \mathrm{~kg} \mathrm{~K} \mathrm{O} \mathrm{ha}^{-1}$ in pot experiment under flooded conditions (Figure 1 and 2), while under aerobic conditions, Basmati-515 yielded better at $\mathrm{K}$ fertilization of $180 \mathrm{~kg} \mathrm{~K}_{2} \mathrm{O} \mathrm{ha}^{-1}$. In field experiment, Basmati-515 performed better than Super Basmati when grown under aerobic conditions. The maximum paddy yield was $1750 \mathrm{~kg} \mathrm{ha}^{-1}$ compared to $1550 \mathrm{~kg} \mathrm{ha}^{-1}$ of Super Basmati at $180 \mathrm{~kg} \mathrm{~K}_{2} \mathrm{O}^{-1}$.

Economic analysis showed that in Basmati-515, K fertilization increased the net benefits at both $\mathrm{K}$ fertilizer levels, however benefit: cost ratio was improved only at 90 $\mathrm{kg} \mathrm{K}_{2} \mathrm{O} \mathrm{ha}^{-1}$ and decreased at $180 \mathrm{~kg} \mathrm{~K}_{2} \mathrm{O} \mathrm{ha}^{-1}$ (Table 3). In Super Basmati, net benefits were more at $90 \mathrm{~kg} \mathrm{~K}_{2} \mathrm{O}$ $\mathrm{ha}^{-1}$ and decreased at $180 \mathrm{~kg} \mathrm{~K}_{2} \mathrm{O} \mathrm{ha}^{-1}$, while benefit cost ratio decreased at both $\mathrm{K}$ fertilization levels. 

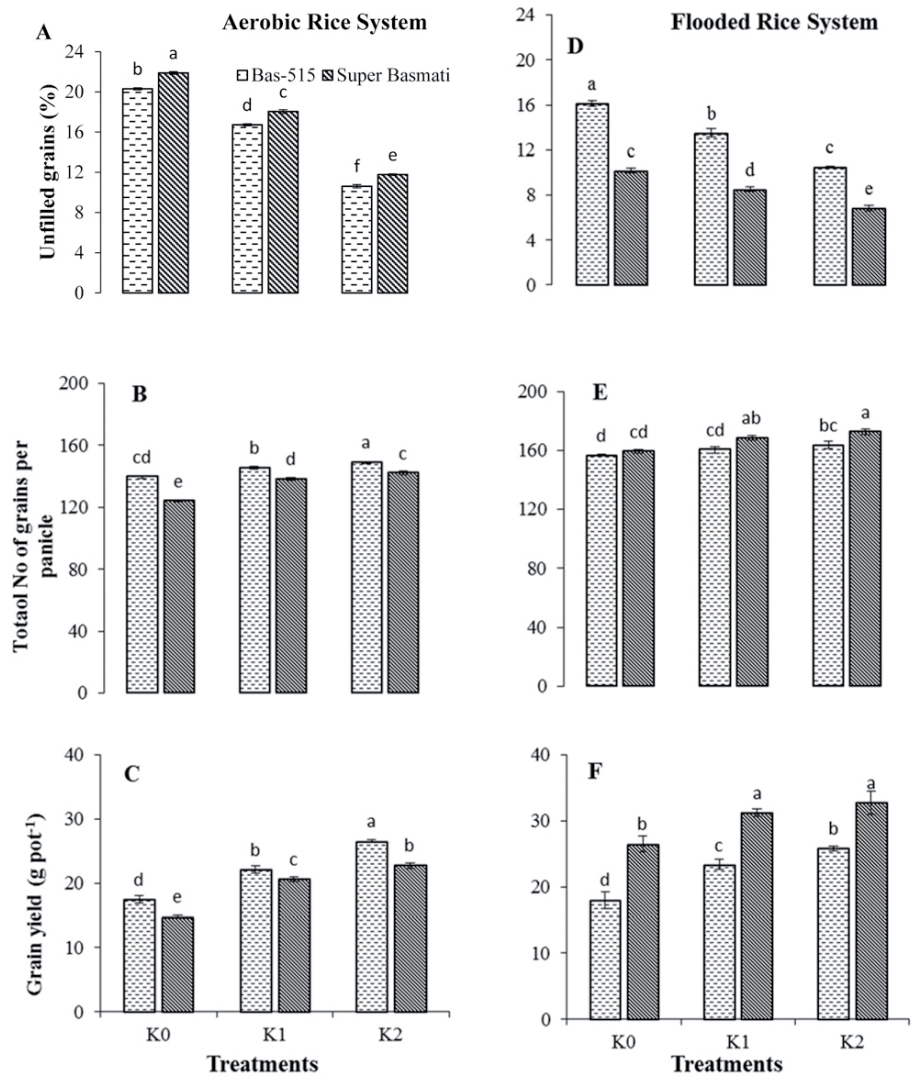

Figure 1. Effect of potassium fertilization on paddy yield in pot experiment. Unfilled grains (A), total number of grains per panicle (B), paddy yield (C) in aerobic rice system, and unfilled grains (D), total number of grains per panicle (E), paddy yield (F). $\mathrm{K}_{0}(\mathrm{No} \mathrm{K}), \mathrm{K}_{1}\left(90 \mathrm{~kg} \mathrm{ha}^{-1}\right)$ and $\mathrm{K}_{2}\left(180 \mathrm{~kg} \mathrm{ha}^{-1}\right)$. Column shows means of four replications while bars show standard error. Means sharing the similar letter (s) do not differ significantly at $\mathrm{P} \leq$ 0.05 according to LSD test. 

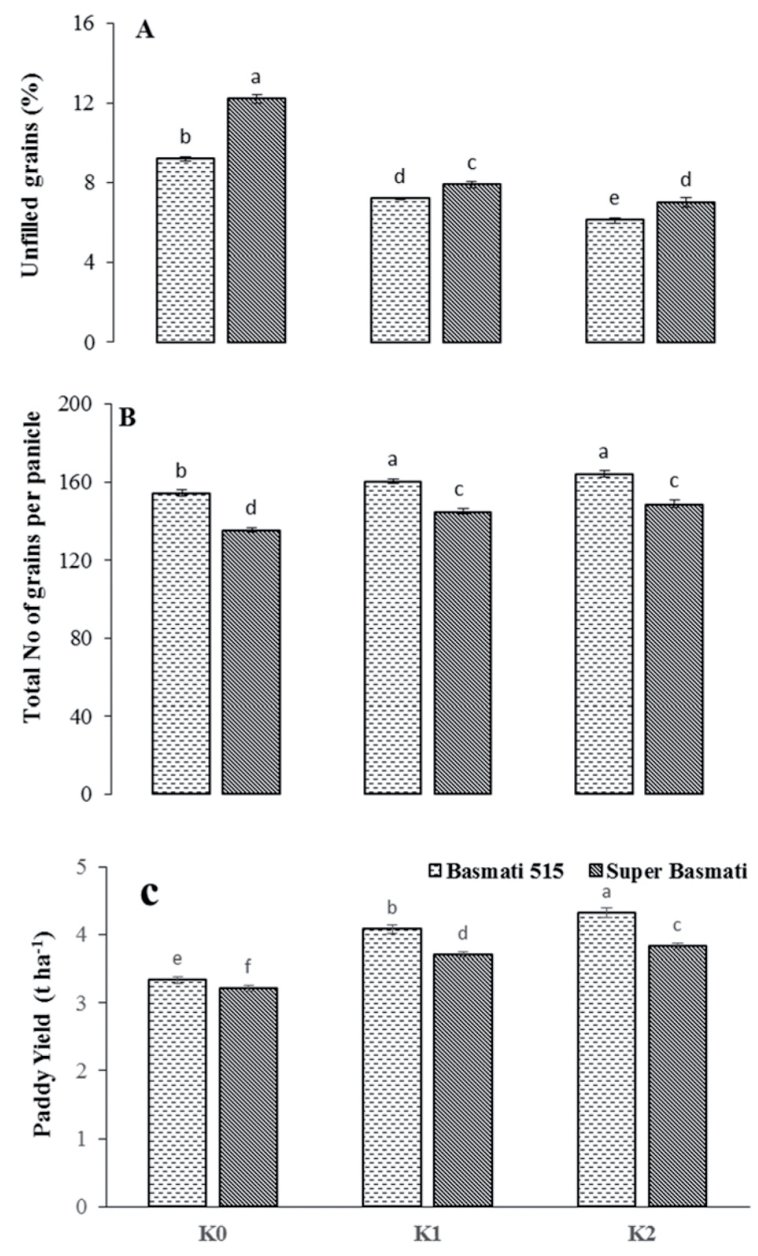

Figure 2. Effect of potassium fertilization on paddy yield in field experiment. Unfilled grains percent (A), total No of grains per panicle (B), paddy yield (C) in flooded rice system. $\mathrm{K}_{0}($ No $\mathrm{K}), \mathrm{K}_{1}\left(90 \mathrm{~kg} \mathrm{ha}^{-1}\right)$ and $\mathrm{K}_{2}\left(180 \mathrm{~kg} \mathrm{ha}^{-1}\right)$. Column shows means of four replications while bars show standard error. Means sharing the similar letter (s) do not differ significantly at $\mathrm{P} \leq 0.05$ according to LSD test. 
Table 3. Economic analysis of application of potassium to rice grown under aerobic conditions where $\mathrm{K}_{1}=90 \mathrm{~kg}$ $\mathrm{ha}^{-1}$ and $\mathrm{K}_{2}=180 \mathrm{~kg} \mathrm{ha}^{-1}$, while $\mathrm{K}_{0}$ mentions control (no $\mathrm{K}$ fertilizer application).

\begin{tabular}{|c|c|c|c|c|c|c|c|c|c|c|c|}
\hline Treatments & & 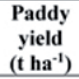 & $\begin{array}{c}\text { Straw } \\
\text { yield } \\
\left(\mathrm{t} \mathrm{ha}^{-1}\right)\end{array}$ & $\begin{array}{l}\text { Paddy } \\
\text { value } \\
(\mathrm{S} \mathrm{ha-1)}\end{array}$ & $\begin{array}{c}\text { Straw } \\
\text { value } \\
\left(\mathrm{S} \mathrm{ha}^{-1}\right)\end{array}$ & $\begin{array}{l}\text { Gross } \\
\text { income } \\
\left(\mathrm{S} \mathbf{h a}^{-1}\right)\end{array}$ & $\begin{array}{c}\text { Permanent } \\
\text { cost } \\
\left(\mathrm{S} \mathrm{ha}^{-1}\right)\end{array}$ & $\begin{array}{c}\text { Variable } \\
\text { cost } \\
\left(\mathrm{S} \mathrm{ha}^{-1}\right)\end{array}$ & $\begin{array}{c}\text { Total } \\
\text { cost } \\
\left(\mathrm{S} \mathbf{h a}^{-1}\right)\end{array}$ & $\begin{array}{c}\text { Net } \\
\text { benefits } \\
(\mathrm{S} \mathrm{ha-1})\end{array}$ & $\begin{array}{c}\text { Benefit- } \\
\text { cost } \\
\text { ratio }\end{array}$ \\
\hline \multirow[t]{3}{*}{ Basmati 515} & K0 & 3.33 & 8.0 & 1831.5 & 80.5 & 1912.0 & 750 & 200 & 950 & 962.0 & 1.01 \\
\hline & $\mathrm{K} 1$ & 4.07 & 6.1 & 2238.5 & 61.1 & 2299.6 & 750 & 382 & 1132 & 1167.6 & 1.03 \\
\hline & $\mathrm{K} 2$ & 4.32 & 7.3 & 2376.0 & 72.9 & 2448.9 & 750 & 564 & 1314 & 1134.9 & 0.86 \\
\hline \multirow[t]{3}{*}{ Super Basmati } & K0 & 3.21 & 4.7 & 1765.5 & 46.8 & 1812.3 & 750 & 200 & 950 & 862.3 & 0.91 \\
\hline & K1 & 3.7 & 4.1 & 2035.0 & 41.1 & 2076.1 & 750 & 382 & 1132 & 944.1 & 0.83 \\
\hline & $\mathrm{K} 2$ & 3.82 & 4.6 & 2101.0 & 45.9 & 2146.9 & 750 & 564 & 1314 & 832.9 & 0.63 \\
\hline \multicolumn{4}{|c|}{ Remarks: $1 \mathrm{~S}=104.1 \mathrm{PKR}$} & $\begin{array}{c}15.9 \mathrm{~S} \text { per } 40 \\
\mathrm{~kg}\end{array}$ & $\begin{array}{c}0.4 \$ \text { per } 40 \\
\mathrm{~kg}\end{array}$ & & $\begin{array}{c}\text { Land rent } \\
\& \\
\text { ploughing }\end{array}$ & & & & \\
\hline
\end{tabular}

\section{Discussion}

Potassium is a mobile element in plants and can be translocated against strong electrical and chemical gradients, and therefore regulate the water movement in different plant parts (Brar and Tiwari, 2004). It is involved in several biochemical and physiological processes that are considered very important for plant growth and yield (Marschner, 1995). Application of $\mathrm{K}$ fertilizers increased the plant height, total biomass and chlorophyll content of rice in present study (Table 2). Earlier, Das et al. (2016) found a positive response to $\mathrm{K}$ fertilization on rice biomass production. Several researchers reported that under water deficit conditions $\mathrm{K}$ uptake and translocation is limited therefore $\mathrm{K}$ fertilization enhance the plant growth, yield, and photosynthetic rate in different crops (Pervez et al., 2004, Wang et al., 2014). In rice, increased application levels of $\mathrm{K}$ fertilizers improved the total biomass production (Samejima et al., 2005) that can be attributed to $\mathrm{K}$ role in transpiration, osmoregulation and stomatal regulation (Cakmak, 2005, Raza et al., 2014). Both levels of $\mathrm{K}$ fertilization increased the $\mathrm{K}$ concentration in shoot at maximum tillering and grains while higher level $\left(180 \mathrm{~kg} \mathrm{~K} \mathrm{~kg}^{-1}\right)$ of $\mathrm{K}$ fertilizer showed increase in $\mathrm{K}$ concentration in husk only (Table 2). Unfilled grains decreased by application of $\mathrm{K}$ fertilizers that were more pronounced under aerobic system (Figure 1). Basmati-515 was more responsive to $\mathrm{K}$ fertilization for decrease in unfilled grains. Potassium fertilization decreased the number unfilled grain under aerobic conditions is very encouraging because panicle sterility is among the major constraints of aerobic rice system (Farooq et al., 2011). Earlier, decrease in panicle sterility has also been reported in rice with application K fertilizers (Awan et al., 2007). In another study, foliar application of $\mathrm{KNO}_{3}$ increased the paddy yield by decreasing the panicle sterility (Mahajan and Khurana, 2014). Because of decreased unfilled grains, the total number of filled grains increased when $\mathrm{K}$ fertilizer was applied (Figure 2). K deficiency creates pollen sterility in rice which reduces the number of filled grains as observed in this study (Figure 1 and 2) (Esfehani et al., 2005). Bahmaniar and Ranjbar (2007) also reported that K fertilization had increased the number of rice grains per panicle. Sufficient $\mathrm{K}$ availability is vital for pollen fertilization and $\mathrm{K}$ response to improve rice yield (Uddin et al., 2013). The results of present study explained that increase in rice yield was due to application of $\mathrm{K}$ fertilizer at both levels because of increased number of grains per panicle with decreased unfilled grains. Application of $\mathrm{K}$ fertilizers increased the $\mathrm{K}$ concentration in shoot at maximum tillering, in husk and grain which 
positively correlate with kernel yield and negatively correlate with unfilled grains (Figure 3) indicating the role of $\mathrm{K}$ in kernel yield improvement by decreasing unfilled grains. However other factors contributing to increased paddy yield at increased $\mathrm{K}$ fertilizer levels can be the promotion of the uptake of other nutrient by producing electric gradient across the plasma membrane of root cells (Marschner, 1995). Although the increase in rice yield has also been observed under flooded conditions, however relative increase in yield was more under aerobic conditions (Figure 4). This indicates less availability of indigenous $\mathrm{K}$ in soil in aerobic system as compared to flooded system, thus signifying the impact $\mathrm{K}$ fertilization in aerobic rice for better production.

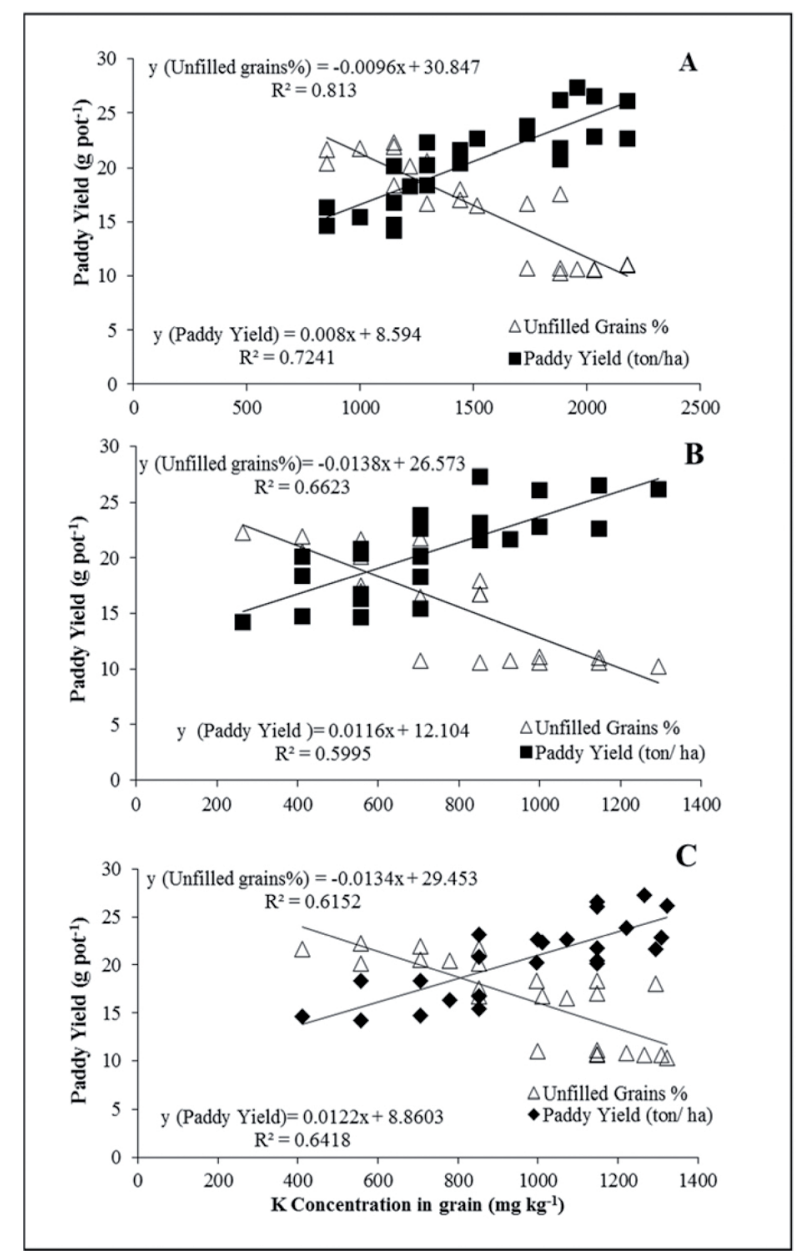

Figure 3. Correlation of $K$ concentration in stem at tillering (A), in husk (B) and rice grain (C) to paddy yield and percent unfilled grains. 

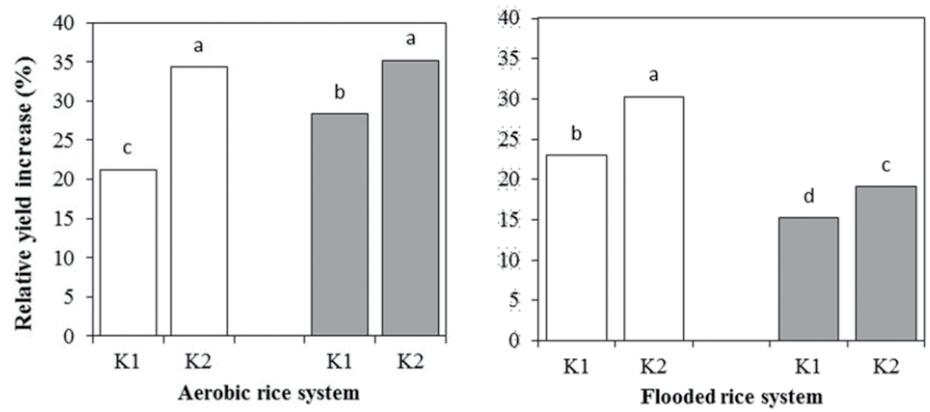

Figure 4. Effect of potassium fertilization on relative yield increase (\%) in pot experiment. Blank columns show the Basmati-515 and dark columns show the Super basmati. $\mathrm{K}_{1}$ (relative increase of $90 \mathrm{~kg} \mathrm{ha}^{-1}$ ) and $\mathrm{K}_{2}$ (relative increase of $180 \mathrm{~kg} \mathrm{ha}^{-1}$ ). Column shows means of four replications and means sharing the similar letter (s) do not differ significantly at $\mathrm{P} \leq 0.05$ according to LSD test.

Economic analysis of field experiment conducted under aerobic conditions expressed that $\mathrm{K}$ fertilization at the rate of $90 \mathrm{~kg} \mathrm{ha}^{-1}$ increased the net benefit in both cultivars, nevertheless the amount of net benefit and benefit cost ratio were more in Basmati-515. Higher level of $\mathrm{K}$ fertilization increased the net benefit in Basmati-515 only, despite decrease in benefit-cost ratio (Table 3). Super Basmati did not show adaptability for aerobic system and benefit cost ration is $<1$ at both $\mathrm{K}$ fertilizer levels and control as well.

\section{Conclusion}

Application of potassium is required under both aerobic and flooded conditions; however, the significance of potash use is more in aerobic system because relative reduction of unfilled grains is more in aerobic system as compared to flooded production system. Therefore, it is recommended to consider potash use for basmati rice in aerobic cultivation system for its better competitiveness with flooded rice cultivation. Further research may be required to quantify the availability of indigenous soil $\mathrm{K}$ under aerobic and flooded conditions. The mechanisms involved for decreased panicle sterility in response to $\mathrm{K}$ application should be investigated to refine findings.

\section{Acknowledgements}

Authors acknowledged the contribution of Mr. Mumtaz Ahmad from Engro Eximp. Sheikhupura, Pakistan.

\section{References}

Akbar, N., Ehsanullah, Jabran, K., Ali, M.A. 2011. Weed management improves yield and quality of direct seeded rice. Aus. J. Crop Sci. 5,688-694.

Awan, T.H., Manzoor, Z., Safdar, M.E., Ahmad, M. 2007. Yield response of rice to dynamic use of potassium in traditional rice growing area of Punjab. Pak. J. Agri. Sci. 44, 130-135.

Bahmaniar, M.A., Ranjbar, G.A. 2007. Response of rice cultivars to rates of nitrogen and potassium application in field and pot conditions. Pak. J. Biol. Sci. 10, 1430-1437. 
Brar, M.S., Tiwari, K.S. 2004. Boosting seed cotton yield in Punjab with potassium. Better Crops, 88: 28-30. J. Plant Nutr. Soil Sci. 168, 521-530.

Cakmak, I. 2005 The role of potassium in alleviating detrimental effects of abiotic stresses in plants. J. Plant Nutr. Soil Sci. 168, 521-530.

Chapman, H.D., Pratt, P.F. 1961. Methods of analysis for soil plant and waters. Barkeley, CA, USA: University of California Division of Agriculture Science.

Das, K.N., Basumatary, A., Ahmad, S. 2016. Targeted yield precision model assessment for ricerice crop sequences in farmers' fields in humid, sub-tropical northeastern India. J. Soil Sci. Plant Nutr. 16, 31-47.

Dawe, D. 2005. Increasing water productivity in ricebased systems in Asia: past trends, current problems and future prospects. Plant Production Sci. 8, 221-230

De Datta, S.K., Mikkelsen, D.S. 1985. Potassium nutrition of rice. p. 665-699. In R.D. Munson (ed.) Potassium in Agriculture. ASA, CSSA, SSSA, Madison, Wl.

De Datta, S.K. 1986. Technology development and the spread of direct seeded rice in Southeast Asia. Exp. Agri. 22, 417-426.

Esfehani, M., Sadrzade, S.M., Kavoosi, M, DabaghMohammad-Nasab, A. 2005. Study on the effect of different levels of nitrogen and potassium fertilizers on growth, grain yield, yield components of rice (Oryza sativa L.) cv. Khazar, Iran. Agron. J. 7, 226-241.

Farooq, M., Basra, S.M.A, Ahmad, N. 2007. Improving the performance of transplanted rice by seed priming. Plant Growth Regul. 51, 129-137.

Farooq, M., Siddique, K.H.M., Rehman, H., Aziz, T, Lee D.J., Wahid, A. 2011. Rice direct seeding: experiences, challenges and opportunities. Soil Tillage Res. 111, 87-98.
Khaliq, A. Matloob, A. 2011. Weed crop competition period in three fine rice cultivars under direct seeded rice culture. Pak. J. Weed Sci. Res. 17, 229-243.

Havlin, J.L., Beaton, J. D., Tisdale, S.L., Nelson, W.L. 1999. Nitrogen. . In J.L. Havlin et al. (ed.) Soil fertility and fertilizers: An introduction to nutrient management. 6th ed. Prentice Hall, Upper Saddle River, NJ. p. 86.153

Hussain, S., Ramzan, M., Akhter, M., Aslam, M. 2008. Weed management in direct seeded rice. J. Animal Plant Sci. 18, 86-88.

Mahajan, G., Khurana, M.P.S. 2014. Enhancing productivity of dry-seeded rice (Oryza sativa L.) in north-west India through foliar application of iron and potassium nitrate. Soc. Plant Res. 27, 301-306.

Marschner, H. 1995. Mineral Nutrition of Higher Plants. 2nd edition. Academic Press, London, UK. pp: 889 .

Patrick, W.H., Mikkelsen, D.S., Wells, B.R. 1985. Plant nutrient behavior in a flooded soil. P. 197228. In O.P. Engelstad (ed.) Fertilizer Technology and Use. 3rd ed. Soil Science Society of America, Madison, Wl.

Pervez, H., Ashraf, M., Makhdum, M.I. 2004. Influence of potassium nutrition on gas exchange characteristics and water relations in cotton (Gossypium hirsutum L.). Photosynthetica. 42, 251-255.

Rashid, M.M. 1999. SabjiBiggan (in Bengali), Rashid Publishing House, 94, Old DOHS, Dhaka. p. 455.

Raza, M.A.S., Saleem, M.F., Shah, G.M., Khan, I.H., Raza, A. 2014. Exogenous application of glycinebetaine and potassium for improving water relations and grain yield of wheat under drought. J. Soil Sci. Plant Nutr. 14, 348-364.

Rehman, H., Basra, S.M.A, Farooq, A., Ahmed, N., Afzal, I. 2011. Seed priming with $\mathrm{CaCl}_{2}$ improves the stand establishment, yield and quality attributes in direct seeded rice (Oryza sativa). Int. J. Agri. Biol. 13, 786-790. 
Rehman, A., Farooq, M., Cheema, Z.A., Wahid, A. 2012. Seed priming with boron improves growth and yield of fine grain aromatic rice. Plant Growth Regul. 68, 189-201.

Rehman, A., Farooq, M., Nawaz, A., Ahmad, R. 2014. Influence of boron nutrition on the rice productivity, grain quality and biofortification in different production systems. Field Crops Res. 169, 123-131.

Rehman, A., Farooq, M., Nawaz, A., Ahmad, R. 2016. Improving the performance of short duration basmati rice in water saving production systems by boron nutrition. Ann. Appl. Biol. 168, 19-28

Samejima, H., Kondo, M., Ito, O., Nozoe, T., Shinano, T., Osaki, M. 2005. Characterization of root systems with respect to morphological traits and nitrogen-absorbing ability in the new plant type of tropical rice lines. J. Plant Nutr. 28, 835-850.

Steel, R.G.D., Torrie, J.H., Dicky, D.A. 1997. Principles and procedures of statistics: A biometrical approach. 3rd ed., McGraw-Hill Book Co. Inc., New York. 352-358.
Timsina, J., Connor, D.J. 2001. Productivity and management of rice-wheat cropping systems: issues and challenges. Field Crops Res. 69, 93-132.

Uddin, S., Sarkar, M.A.R., Rahman, M.M. 2013. Effect of nitrogen and potassium on yield of dry direct seeded rice cv. NERICA 1 in aus season. Int. J. Agron. Plant Production. 4, 69-75.

Wang, X., Mohamed, I., Xia, Y. 2014. Effects of water and potassium stresses on potassium utilization efficiency of two cotton genotypes. J. Soil Sci. Plant Nutr. 14, 833-844.

Wassmann, R., Neue, H.U., Ladha, J.K., Aulakh, M.S. 2004. Mitigating greenhouse gas emissions from rice-wheat cropping systems in Asia Environment. Sustainable Develop. 6, 65-90.

Zaman, U., Ahmad, Z., Farooq, M., Saeed, S., Ahmad, M., Wakeel, A. 2015. Potassium fertilization may improve stem strength and yield of basmati rice grown on nitrogen-fertilized soils. Pak. J. Agri. Sci. 52, 439-445. 